Once you have Acrobat Reader open on your computer, click on the Comment tab at the right of the toolbar:

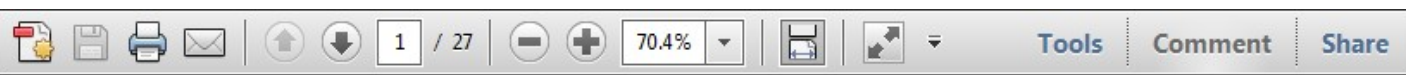

This will open up a panel down the right side of the document. The majority of tools you will use for annotating your proof will be in the Annotations section, pictured opposite. We've picked out some of these tools below:

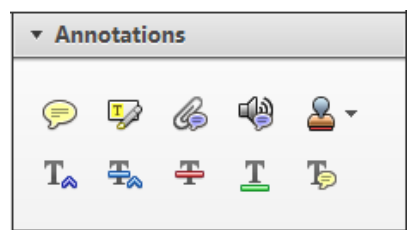

\section{Replace (Ins) Tool - for replacing text.}

Trikes a line through text and opens up a text box where replacement text can be entered.

\section{How to use it}

- Highlight a word or sentence.

- Click on the Replace (Ins) icon in the Annotations section.

- Type the replacement text into the blue box that appears.

ıdard tramework for the analysis of $\mathrm{m}$ icy-Nevertheless, it also led to exog،

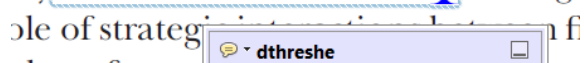
aber of comp 08/06/2011 15:58:17 $\quad$ O

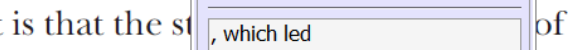
nain compo: be level, are exc nc

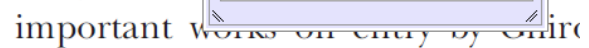
M henreforth) ${ }^{1}$ we onen the 'hlarl t

3. Add note to text Tool - for highlighting a section to be changed to bold or italic.

T. Highlights text in yellow and opens up a text box where comments can be entered.

\section{How to use it}

- Highlight the relevant section of text.

- Click on the Add note to text icon in the Annotations section.

- Type instruction on what should be changed regarding the text into the yellow box that appears.

namic responses of mark ups ent with the VAR evidence

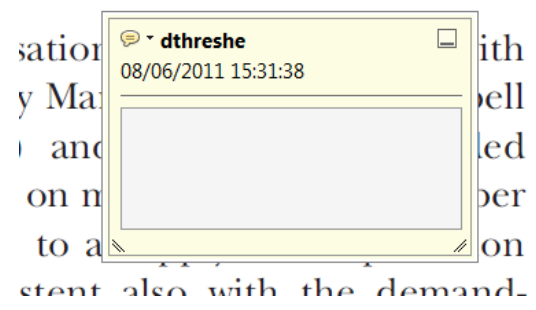

\section{Strikethrough (Del) Tool - for deleting text.}

T. Strikes a red line through text that is to be deleted.

How to use it

- Highlight a word or sentence.

- Click on the Strikethrough (Del) icon in the Annotations section.

there is no room for extra protits al s ups are zero and the number of zet) values are not determined by Blanchard and Kiyotaki (1987), sfect competition in general equilil ts of aggregate demand and supply lassical framework assuming monol ean an evorensuc numher of firme

\section{Add sticky note Tool - for making notes at} specific points in the text.

\section{Marks a point in the proof where a comment} needs to be highlighted.

How to use it

- Click on the Add sticky note icon in the Annotations section.

- Click at the point in the proof where the comment should be inserted.

- Type the comment into the yellow box that appears.

iailu ailu suppiy siluks. Hivsl vi

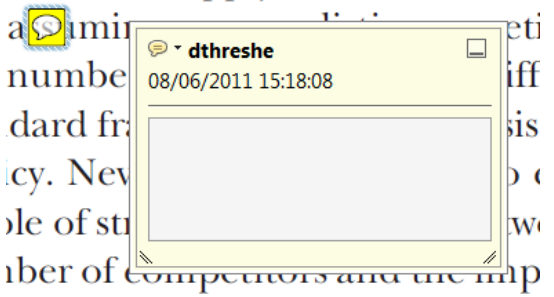

lber of "

is that the structure of the sects 
5. Attach File Tool - for inserting large amounts of text or replacement figures.

Inserts an icon linking to the attached file in the appropriate place in the text.

\section{How to use it}

- Click on the Attach File icon in the Annotations section.

- Click on the proof to where you'd like the attached file to be linked.

- Select the file to be attached from your computer or network.

- Select the colour and type of icon that will appear in the proof. Click OK.

E N D

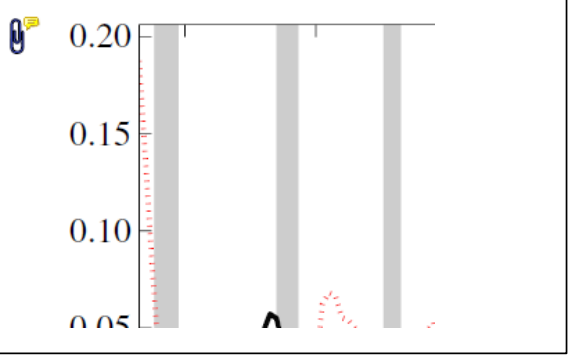

6. Drawing Markups Tools - for drawing shapes, lines and freeform annotations on proofs and commenting on these marks.

Allows shapes, lines and freeform annotations to be drawn on proofs and for comment to be made on these marks.

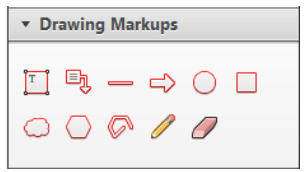

How to use it

- Click on one of the shapes in the Drawing Markups section.

- Click on the proof at the relevant point and draw the selected shape with the cursor.

- To add a comment to the drawn shape, move the cursor over the shape until an arrowhead appears.

- Double click on the shape and type any text in the red box that appears.

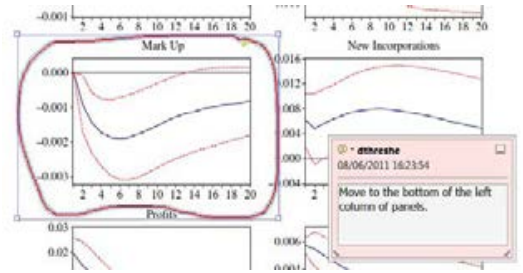




\title{
The silencing effects of the childhood innocence ideal: the perceptions and practices of fathers in educating their children about sexuality
}

\section{Clare Bennett ${ }^{1}$, Jane Harden ${ }^{2}$ and Sally Anstey ${ }^{2}$}

${ }^{1}$ Institute of Health \& Society, University of Worcester, UK

${ }^{2}$ School of Nursing and Midwifery Studies, Cardiff University, UK

\begin{abstract}
This study employed Interpretative Phenomenological Analysis to explore eight fathers' perceptions and practices in talking to their ten year old children about puberty, relationships and reproduction. The fathers participated in face to face interviews which were analysed idiographically initially, followed by analysis at the group level. Interpretations were then developed through critical application of a Foucauldian lens of governmentality and biopower. The results revealed a tension between the fathers' cognitions, accounts and behaviours. Their practices were largely characterised by silence yet they reported positive attitudes towards children's sexuality education and perceived themselves as equipped and willing to take on the role of sexuality educator. They also reported enjoying open relationships with their children. Interpretations centred on contradictions and conflict between the majority of the fathers' aspirations and the compelling nature of the childhood innocence discourse as a technology of governmentality. Whilst all of the fathers felt that it was in their children's interests to learn about sexuality, all but one adhered to hegemonic protective discourses and unquestioningly integrated their normalising effects into their fathering practices which, it is argued, may paradoxically render their children more vulnerable both now and in the future.
\end{abstract}

Keywords: parenting/parents, sexual health, Foucault

\section{Introduction}

Throughout the last decade, a growing body of literature has suggested that parent-adolescent communication about sexuality can be a protective determinant of sexual risk-taking behaviour during adolescence (Campero et al. 2011, Huebner \& Howell 2003, Lehr et al. 2000, Miller et al. 2001, Nagamatsu et al. 2008, Ogle et al. 2008, Somers \& Paulson 2000, Widman et al. 2006, 2016). However, whilst there is a burgeoning literature concerning the challenges that parents encounter in undertaking this role, there is a paucity of research which specifically examines parents' experiences of sexuality communication with their pre-adolescent children. The few studies that exist suggest that parents struggle in fulfilling this aspect of parenting (Ballard and Gross 2009, Davies and Robinson 2010, Frankham 2006, Geasler et al. 1995, 
Stone et al. 2013, 2015a, 2015b) but there has been little analysis of why parents report such challenges.

Sexual thinking is very much present in the worlds of young children who continually observe aspects of sexuality in their daily lives and seek to understand and integrate their perceptions into their personal schema (Best 1983, Renold 2005, 2013). Goldman and Goldman (1982) identified that if explanations are not available to children they will invent theories for themselves in order to make sense of their sexual world. Children not only seek sexual knowledge but they strive to understand it and make sense of it. However, children's efforts are frequently thwarted by taboos enforced by sometimes evasive, repressive or even coercive behaviours by adults.

2 The study, from which this article has been developed (*Anon 2015), sought to add to the current limited body of knowledge about parent-child sexuality communication. However, rather than focusing on 'parents', a more nuanced approach was taken which focused specifically on fathers since their experiences are largely over-looked in the literature and there is a consensus that further work in this field is required (DiIorio et al. 2003, Walsh et al. 1999, Widman et al. 2016, Wilson et al. 2010, Wilson and Koo 2010, Wyckoff et al. 2008). The research question that guided this study was, therefore: 'What are the perceptions and practices of fathers in educating their children about physical maturation, reproduction and relationships?'

The aims were:

1. To develop a critical understanding of the practices of fathers in engaging in sexuality communication with their children.

2. To surface the perceptions of fathers concerning their role in engaging in sexuality education with their children.

3. To reveal fathers' attitudes towards children's sexuality education.

\section{Methodology}

This study employed Interpretative Phenomenological Analysis (IPA) which was developed and refined by Smith et al. (Smith 1996, 2004, Smith and Eatough 2016, Smith et al. 2009). Philosophically IPA is informed by phenomenology, hermeneutics and idiography. IPA is also influenced by symbolic interactionism with its concern for how meanings are constructed by individuals within both their social and their personal world. IPA has a dual aim of providing an in-depth exploration of people's lived experiences as well as an examination of how people make sense of these experiences (Smith et al. 2009). It also facilitates a focus on social cognition in that it is concerned "with unravelling the relationship between what people think (cognition), say (account) and do (behaviour)' (Smith and Eatough 2012: 442) which was of particular value to this study since it was concerned with both the perceptions and practices of fathers.

\section{Theoretical Framework}

The theoretical framework for this study was Foucault's concepts of governmentality and biopower. Conceptually, governmentality originates from the work of Foucault (1979). It refers to the 'subtle, comprehensive management of life drawing both from a top-down exercise of power over conduct ... with a subjectivity constituted in a sense of personal responsibility, 
rights, freedoms and dependencies' (Fox 1993: 32-3). Governmentality is characterised by pervasive surveillance and disciplining of the individual and the population 'in relation to a whole series of power networks that invest in the body, sexuality, the family, kinship, knowledge, technology and so forth' (Foucault 1978: 122). Foucault (1978: 140) argues that governmentality's continuous surveillance and corrective mechanisms make bodies transparent and render them open to manipulation, thus fostering the emergence of 'biopower'. Biopower refers to the 'technologies of power that address the management of, and control over, the life of the population' (Nadesan 2008: 2). It is concerned with maximising the functionality of individuals, families, the economy and the state and promoting social discipline (Beck 1992). For Foucault, biopower was the dominant system of social control in modern Europe throughout the 20th century since it constructs truth discourses concerning 'normal' sexuality and it also produces authorities who exert power in speaking about them, thus enabling subjugation (Rabinow and Rose 2006). Unlike previous regimes which exerted power over life, biopower brings 'life and its mechanism into the realm of explicit calculations and made knowledge-power an agent of transformation of human life' (Foucault 1978: 143).

\section{Methods}

Recruitment of participants was via advertisements placed at a university, sports clubs, community groups and social networking sites. A total of eight fathers volunteered and they were all recruited to the study. The sample was homogenous, a quality which is advocated for IPA studies (Smith et al. 2009). All of the fathers had children who were aged ten and in year five of the English school system and they lived with their children and their children's mothers full-time. They were all white, heterosexual and similar in age (forty-two to forty-six years) and were professionals, educated to Masters level or equivalent.

Data collection was via individual face-to-face interviews which lasted between 30 and 72 minutes. All interview recordings were transcribed verbatim and data analysis was carried out as per Smith et al.'s (2009) guidelines. Thus, analysis was an iterative and inductive process with each interview analysed separately initially. Each transcript was analysed line by line and initial descriptive notes were made, followed by observations of the language used and semantic content and finally, conceptual comments were recorded which, in due course, became themes. The process was cyclical in that emerging themes were tested against earlier data and themes were, on occasion, changed to become subordinate or superordinate.

The School of Healthcare Sciences Research Ethics Committee at Cardiff University granted approval for this study. The study adhered to the approved proposal throughout. Informed consent was obtained from all participants both in relation to their participation in the study and subsequent publication of findings. All quotations in the ensuing discussions have been anonymised in order to safeguard the confidentiality of participants and pseudonyms have been used throughout for the fathers, their children and their partners.

\section{Results}

The following section reports on the study's findings pertaining to 'Childhood Innocence' at the idiographic level, followed by a cross-group analysis. 


\section{Michael}

Michael felt that he had a close relationship with his son and he was confident that his son could talk with him openly:

Henry and I have got a good relationship. We talk, you know umm we're open with each other...

Michael described feeling equipped to teach his son about puberty, relationships and reproduction and he felt that it was a parental responsibility to do so, however, he had not engaged in such discussions with Henry:

On the sexual side I probably haven't actually approached it in a, as a are you ready for a talk yet? I don't, I don't think I've said if you ever want to talk.

Michael appeared to perceive Henry as younger than he was chronologically and did not acknowledge that his son was growing up and approaching a period of physical and emotional change:

Interviewer: How about say puberty? At around this age, some boys start to change don't they?

Michael: Umm.

Interviewer: They might grow body hair, have wet dreams and so on? Have you talked about those kinds of changes?

Michael: $\quad$ No I haven't no.

Interviewer: Has it occurred to you?

Michael: No it probably hasn't. I don't think he is close to that stage ...

Interviewer: When do you think children are ready to know about puberty, relationships and reproduction?

Michael: I don't think Henry is yet ... he hasn't shown any interest [in girls] yet.

This last response suggested that whilst the interviewer, was talking about three areas of learning, Michael had aggregated these three aspects to one, interpreting the conversation as being concerned only with (hetero)sexual relationships. The dialogue suggested that since such conversations would focus on sex they would be irrelevant to a ten year old:

He's not ready ... there's no need yet.

Thus, a silence characterised Michael's treatment of sexuality which he attributed to his son's lack of readiness for these types of discussions.

\section{Nigel}

Nigel felt strongly that educating children about puberty, relationships and reproduction was 'the parents' responsibility' and 'you shouldn't shirk it'. He reflected on his own parents' lack of communication with him about intimate issues and he wanted to be better than them in this regard. He described feeling knowledgeable and confident in undertaking this role and said that he had an 'open and honest' relationship with his children yet he had not discussed any aspect of puberty, sex or relationships with his son Tom, who was ten. Nigel appeared to not see his son as he really was chronologically and developmentally; his overall perception of his son was that he was innocent and, therefore, asexual: 
He really doesn't need to know yet. It's not relevant to him. Perhaps when he's going to secondary school but not now, he's more into playing than all that stuff.

Angus

Angus spoke passionately about how knowledge can protect children from emotional and physical harm:

Knowledge protects them. They need to be aware of everything that is going on for them. As individuals, they need to be aware of what is going on with their bodies, so they aren't worried about it and they need to be aware of relationships and that there are all sorts of people in this world, some of them are good, some of them will try and help you and some will do the opposite and that's how life is.

In articulating this belief, Angus's language was fluent and confident and his line of argument was clear. His assertions were underpinned by a belief that children required support and protection, however, in using 'they' it appeared that Angus was talking about children in general as opposed to his own. Angus stated that it was a parental responsibility to teach children about sexuality and described feeling equipped to fulfil this role, yet his lived experience of discussing sexuality with his own children appeared to be very limited. As the conversation moved from the general to the personal lived experience the change in the linguistic characteristics of his speech were striking. When asked about his daughter's knowledge of periods and other aspects of puberty and her awareness of how babies are made, Angus responded:

Angus: I don't know, it's weird to think about as I've never thought about it.

Interviewer: Do you plan to check that out?

Angus: I am not sure I do, I don't know ... I'm not sure that she is ready yet, she still likes her dolls and stuff like that.

Thus a tension emerged between Angus's beliefs and his behaviours in the home in that he believed that knowledge can be protective for children but he felt that sexuality-related communication was superfluous to his daughter's needs at this time.

\section{James}

James voiced his concern about threats to childhood innocence:

... Rich, he's ten so a bit early, but he's showing an interest in girls now and I don't think he's equipped to deal with that ... I am terrified that his innocence is going to be taken away.

However, a conflict between James' perception of childhood as a time of innocence and the realities of his son Rich's life emerged from the transcript: 'he's gone out with about ten girls and that doesn't actually mean going out with them but sitting in the bike shed kissing which is very sweet'. James was describing sexualised behaviour yet he described it as 'very sweet' which portrayed it as innocent as opposed to tainted or worldly. Although James described himself as having 'enough knowledge' he was not proactive in discussing sexuality related issues with his son. Instead he relied upon Rich to ask questions which did not happen. Whilst he felt that it was a parental responsibility to teach children about sexuality and he believed that knowledge can be protective, he was not proactive in fulfilling his aspirations to be open 
and supportive of Rich in this regard which resulted in a complete void with regards to this aspect of James' communication with his son.

\section{Steve}

Steve was explicit in relation to discussing the tension between his perception of his daughter, Lydia, as innocent yet, simultaneously, physically developing:

You can see Lydia growing up now, but she - in her outlook and the way she wants to be

- she is completely a little girl, drinking her milk out of a baby's cup and playing little girls' games ... So the thought of talking about growing up, sexual relationships and reproduction I just can't see how we will do it ...

Despite observing that Lydia had already commenced puberty, physically she's starting to grow up' Steve still saw her as a little girl; thus there was a conflict between Lydia as she really was and his perceptions of her. He saw Lydia as 'other' but she was on the cusp of changing to become the 'same' in the form of an emerging adult yet Steve appeared to be silenced by his perceptions of Lydia as young and innocent.

\section{Colin}

Colin's experience of parent-child sexuality education had an exclusively biological focus:

Colin: Jake asked me a question and we covered it all in fifteen to twenty minutes.

Interviewer: When you say 'covered it all', what did you cover?

Colin: Sexual, erm we did a little, yes we did. Obviously not in graphic detail but how the sperm gets in and penetrates the egg and we did do menstruation as we are an open family. He's asked questions like what's that on the toilet, it's a bit of blood and I have said 'it happens to mum sometimes'.

Colin asserted that 'it's the parents' responsibility' to impart sexuality education. He painted a picture of openness, for example: 'we are an open family' and 'I don't think you should make it a taboo'. However, a second reading revealed a tension between 'openness' and 'control'. Whilst Colin felt that he had been open and responsive he had actually addressed very little. Although Colin described his son as 'a bright spark', the limitations to discussions imposed by Colin appeared to link to his perceptions of age appropriateness and how much he felt Jake needed to know:

Colin: If he asks a question, I tell him the truth but I suppose you're economical with it ...

Interviewer: When you've talked about sex have you talked about the relationship side of things?

Colin: No I don't think that's appropriate for his age, and I could gauge from his reaction he would not cope, he would be pulling a face and saying 'Oh no'!

Thus Colin appeared to apply a framework of varying shades of openness to his parenting in this regard which appeared to be underpinned by notions of age appropriateness and childhood innocence.

\section{Neil}

Protective discourses characterised much of Neil's dialogue. He drew upon both his personal and professional experiences and his personal values to create a world view which privileged perceptions of risk and the need to protect children, for example: 
We talk about how some adults can't be trusted and stranger mentality where you think 'I don't know this person, I am not going to go off with them'. It's that naivety and gullibility you've got to touch on without removing their innocence and childhood.

Risks included normalising messages regarding promiscuity on the television and predators that his children may come in to contact with, either through the internet or through their day to day lives. These risks caused Neil significant anxiety as illustrated by his use of language, for example he used the terms 'it's just horrific' and 'it does worry me' several times and he described employing protective behaviours such as discouraging his daughter from joining community groups and restricting his children's internet usage.

Neil described feeling equipped for the role of sexuality educator and his behaviours were consistent with his aspirations to be open with his children. For example, he described some of the more 'factual' discussions that he had had with his son, Tony, when he was age ten:

I said that every twenty eight daysish a girl loses the lining of the womb and it leaks out through her vagina so they need tampons and panty liners to stop it being embarrassing, smelly or staining clothes.

We talked about blokes first of all and sex. It was sort of talking slang terms for penis, vagina and sex. We talked about erections, hard-ons.

We've talked about masturbating.

The linguistic qualities of Neil's transcript suggested that he was comfortable and confident in discussing these issues with his son. Metaphor and euphemism were not a feature of his dialogue; his language was factual and unembarrassed. Although Neil was concerned about preserving his children's childhood innocence he felt that possession of factual information could be protective, thus enabling them to safeguard their sexual innocence.

Andy

Andy had given his role in talking about sexuality with his daughter, Charlotte, very little thought prior to the interview. When asked whether he had any opinions regarding the age that children should learn about sex and relationships he responded:

The thinking is that girls mature quicker than boys do. I reckon if Charlotte knows more about sex earlier it's a good thing as she will be more street wise. But that's if you think she can cope with it. It depends on the child, if you think they are fairly immature then you don't want to be telling them too much at that time. It's making sure you give them enough information that they can cope with at that time and give them bits to go away with and come back at a later point to go through further. I think if she's confident to ask questions or won't get too upset then I think ten, eleven, and twelve, after that it's a bit late.

This extract suggests that age appropriateness and levels of maturity were important to Andy in relation to determining when sexuality should be discussed with children. The age range that he mentioned, age ten to twelve, included Charlotte's age, however, he did not appear to connect this statement to Charlotte's needs. Similarly, he did not seem to link his statement about the potentially protective role of knowledge to Charlotte at this stage in her life, instead his focus appeared to be on a notional future. Furthermore, although earlier in the interview Andy had asserted that 'parents have a responsibility' and he indicated that he felt that he would be capable of undertaking the role of sexuality educator if he had to, 'I'd probably go 
on the internet. The resources are there ... I can muddle through, I'm sure', his practices as a sexuality educator were characterised by an absence of meaningful dialogue.

Thus, although Andy felt that girls need to know about sexuality related issues at an early age because they 'mature quicker than boys' and he felt that it was advantageous for them to learn about relationships and sex, he was completely unaware of Charlotte's level of understanding. Whilst he reported feeling equipped to undertake this role and considered it a parental responsibility there was significant dissonance between these assertions and his behaviours which appeared to relate to constructions of his daughter as being developmentally less mature than she was in reality.

\section{Analysis at the group level}

All of the fathers agreed that discussing sex, relationships and puberty with their children was a parental responsibility and the majority felt that knowledge about these issues would protect their children emotionally and physically. All but one of the fathers described themselves as equipped for the role, yet only one, Neil, had addressed sexuality comprehensively with his children. The children that were discussed in these interviews were aged ten and were, therefore, likely to be peri-pubertal or pubertal. However, all of the fathers apart from Neil considered their children to be too young to require information about puberty, relationships and reproduction. The fathers shared a perception of their children as innocent and/or 'not ready' which appeared to give rise to an over-arching silence regarding father-child sexuality, regardless of whether the child was male or female. The subordinate themes that emerged from the fathers' data are presented in Figure 1 which demonstrates the relationship between the subordinate themes and the emergence of the superordinate theme 'childhood innocence'.

\section{Discussion}

\section{Innocence}

Whilst the fathers' lived experiences of fatherhood and masculinities were central to interpreting the findings of this study (*Anon 2015) their practices were contingent on wider issues concerning regimes of truth regarding the condition and status of childhood. Jackson and Scott (2010: 101, 103) describe sexuality as being seen by many as 'inimical to childhood itself' and 'antithetical to the well-being of children' since it is widely regarded as a threat to the childhood innocence ideal. The findings of this study were in keeping with those of Egan

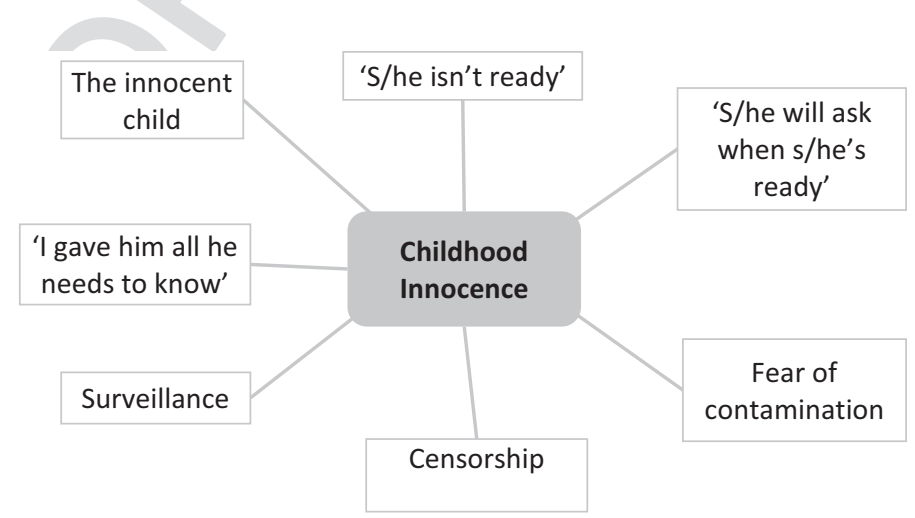

Figure 1 Development of the superordinate theme 'Childhood Innocence' 
(2013), Goldman and Goldman (1982) and Robinson (2013) in that the fathers perceived their children as asexual in their thoughts and behaviours and they were viewed as innocent and unaffected by sex. These perceptions were in keeping with notions of the Romantic child which dates back to the late eighteenth century. Children were portrayed as asexual, pure and innocent and thus, the innocent child ideal emerged which led to the normalisation of practices that aimed to shield children from an awareness of sex and sexuality. Childhood, therefore, became a site of public and private surveillance and childhood sexuality became the object of intense scrutiny which was pivotal in deploying a shift in disciplinary apparatus, most notably through the family, which foregrounded the project of normalisation and surveillance in the late nineteenth century (Foucault 1978). This project strengthened further in the first two decades of the twentieth century with the emergence of psychoanalysis and sexology which identified the potential for children to be sexual.

Several studies have identified that parents' concerns to protect their children's innocence can present a barrier to parent-child sexuality communication (Dyson and Smith 2012; Stone et al. 2015a, 2015b, 2013, Walsh et al. 1999). McGinn (2013) found that although there is some ambiguity on the part of parents in defining childhood innocence, definitions generally centre on two key areas: the non-sexuality of children and their lack of sexual knowledge. These definitions applied to the present study with the fathers assuming that their children lacked knowledge about sexuality, coitus and their own bodies and they were, therefore, innocent. However, the fathers' assumptions were based on their lack of dialogue with their children about sexuality and appeared to overlook spatiality, in that they underestimated the learning that their children were likely to have acquired through their exterior worlds such as school friends, friends' families and observing people's bodies and relationship behaviours in public spaces. Whilst some reference was made to playground learning by Michael and James, and Andy made reference to Charlotte having support through the extended family and friends, the fathers largely appeared to overlook the impact of the children's inner worlds on their learning, for example their interactions with books, television, films, art and social media all of which portray different aspects of sexuality.

Relationality or the 'otherness of the other' is at the heart of social constructions of childhood. This was evident in the fathers' transcripts with the children being described as too young to cope with learning about sexuality by all of the fathers apart from Neil. Developmental perspectives were clearly evident in the fathers' perceptions of childhood. Stone et al. (2015a, 2015b) identified that this was a concern amongst the 110 parents that participated in their research and Nguyen and Rosengran (2004) also identified that this was the case in their study, with parents believing that issues of a sexual nature should be discussed later than other biological concepts.

Thus, boundaries and barriers were applied by the fathers which privileged the 'knowledgeable' adult over the 'naïve' or 'ignorant' child. However, with no clear demarcation between what constitutes adulthood and, therefore, childhood, definitions of age or stage appropriateness are problematic. The notion of a threshold between child and adulthood was hinted at by the fathers and appeared to include several reference points: the development of competence, the loss of innocence and physiological sexual development. Alanen and Mayall (2001) emphasise the social construction of age, time and temporality of childhood and Lee (2002) furthers the debate by challenging notions of competency, emphasising that competency is context dependent in that adults and children can be simultaneously competent and incompetent depending upon what is being demanded of the individual. However, Robinson (2008) and Jackson and Scott (2010) argue that the defining boundary between adulthood and childhood is childhood innocence and hegemonic discourses of sexuality suggest that physiological sexual maturity is a signifier of adulthood (Robinson 2008). As Foucault (1978) notes, in 
modernity, the child's sexuality was conceptualised as physiologically present, but experienced as subjectively and phenomenologically absent until puberty. Thus the fathers' discourses were congruent with the dominant discourse that children are, therefore, non-sexual. By perceiving their children as innocent, childhood could be prolonged by the fathers and time was temporarily suspended in that roles were unchallenged and remained unchanged.

In relation to temporality all of the fathers, apart from Neil, appeared to experience a tension between objective time, that is their children's chronological age and stage of development, and their subjective, lived time whereby the children appeared to be perceived by their fathers as being much younger physically and less knowledgeable than they were in reality. For example, the girls that were referred to by their fathers were either peri-pubertal or pubertal and Nigel's son, Jo, had already learnt about reproduction before his father broached the issue with him, yet the fathers continued to perceive the children as 'not yet ready' to talk about sexuality. Temporality discourses surrounding 'being' and 'becoming' (James 1998) were, therefore, also of relevance to interpreting the findings of this study. The 'being' child is regarded as exercising agency in constructing their personal childhood whereas the 'becoming' child is perceived as an 'adult in the making' and lacks the essential skills and competencies of the adult that they will become (James and James 2004). Neil's discussions focused on preparing his children to become the competent, confident adults that he hoped they would be, whereas the other fathers appeared unable to think beyond their perceptions of the present. James and Prout (1997) assert that the dominant framework in contemporary Western European society is the 'becoming' child, however, the findings of this study question this position.

A further finding of this study relating to both constructions of childhood and temporality, concerned the age of the children that were the focus of the interviews. Many of the findings of the current study resonate with Davies and Robinson's (2010), Stone et al.'s (2015a, 2015b, 2013) and Walsh et al.'s (1999) in that many of the parents who participated in these studies felt that discussing bodies, relationships and reproduction with young children was unnecessary and may pose a threat to childhood innocence. However, an important difference between these studies and the current study concerned the age of the children under discussion; the children in the studies cited were aged three to six years, whereas the parents in the current study were reflecting on the needs of their ten year olds. Thus it appeared that the image of the sexually innocent child extended well beyond the early years for the fathers in this study. With the exception of Neil, the fathers' lived experiences were embedded in a protracted sense of time in relation to their biographies as fathers of young children and the duration of early childhood.

\section{Protective discourses}

Discourses are historically and culturally developed practices through which knowledge, power and subjectivity can be understood (Foucault 1972). A protective discourse characterised much of the fathers' collective narrative with the assertion that knowledge about sex and relationships could protect their children from predators. The children were perceived as emotionally and cognitively immature by their fathers and, therefore, vulnerable. Such concerns are representative of the wider literature such as Stone et al.'s (2015a, 2015b, 2013) and Dyson and Smith's (2012). In addition, they reflected the prevailing media discourse in the UK at the time of data collection concerning ongoing revelations about the perpetration of sexual abuse by several high profile media personalities which had exacerbated public anxiety about 'the paedophile' as a threat to children's safety.

Jackson and Scott (2010) suggest that such anxieties are associated with changes in the social world which is becoming less stable and predictable. Thus, protective discourses have endured and grown with risk anxieties superimposed on to a normalised set of risk 
assumptions about childhood and sexuality. Consequently, a preoccupation with prevention against any potential threats to the wellbeing of children with regards to sexual knowledge has emerged both within the private domain of parenting and health promotion discourses (Jackson and Scott 2010). Harden (1998) posits that such discourses present contemporary examples of biopower with prescriptions for the protection of children's welfare linking private acts to the 'public good'. A cultural perception of the childhood innocence ideal coupled with the concept of risk are argued to act together to galvanise parents to pursue the safeguarding of their children's wellbeing as a goal, although keeping children in ignorance does not necessarily protect them effectively and may, paradoxically increase their vulnerability (Jackson and Scott 2015, Robinson 2013). As Foucault (1978) asserts, the repressive discourses of the Victorian era surrounding sexuality intensified the focus on the sexual and by insisting so loudly on the innocence, purity and asexuality of the child, we have created a subversive echo: experience, corruption, eroticism' (Kincaid 1992: 4). Chenier (2012) argues that the social construction of the sexual predator serves to support the ideological function of the white, middle-class, gendered, hierarchical, heterosexual family and, thus, 'stranger-danger' discourses maintain the 'natural order of disorder' (Foucault 1978: 44). As Foucault (1978: 44) asserts aberrant sexualities are not suppressed, they are, instead, subject to analytical scrutiny and 'made into a principle of classification and intelligibility' in order to maintain societal order. By externalising threats to childhood innocence through the predator discourse, which directs the gaze to the stranger and distracts from the family, the fictional ideal of the family as safe and nurturing is maintained (Chenier 2012). Thus, the sexual deviant is both an effect of and a strategy of power in that the paedophile has been seen by many as defining sexual innocence (Chenier 2012).

For the fathers in the current study, the reluctance to discuss sexuality related issues with their children appeared, in part, to relate to an anxiety regarding premature sexualisation of their children. All of the fathers expressed concern that their children were being exposed to too much sexualised imagery and this could be harmful to them emotionally. Martin and Torres (2014) propose that such concerns reflect the traditional assumption that children are passive in their sexual socialisation. However, childhood sociologists such as James and Prout (1997) and Corsaro (1992) and the developmental theorist Vygotsky (1978) argue that children are far from passive in that they interpret, engage and interact with the world around them to evaluate and make sense of their sexual socialisation. Indeed, Buckingham and Bragg's (2004) analysis of interview and diary data of 120 nine to 17 year olds demonstrated that children and young people assert agency in interpreting and assimilating sexual messages that they are exposed to through adult and youth media. Rysst (2010) and Pilcher (2010) have also demonstrated how adult interpretations of girls' fashion are frequently at odds with adult interpretations in that adults assume that girls want to look 'sexy' and provocative whereas the girls talk about wishing to look 'grown up' and 'cool'. Thus, children appear to assert agency and interpret 'adult' materials in more complex and nuanced ways than adults frequently assume (Renold 2013; Wyness 2015). Thus, Foucault's (1978) assertion that sexuality must be understood through the politics of talk and that sexuality is organised spatially and materially is of relevance here in that these studies demonstrate that children themselves question the politics that sustain the dichotomy between child and adult sexuality.

The fathers all described engaging in types of surveillance in relation to their children's internet and television usage, with music videos and social media featuring as particular sources of concern. They felt that exposure to such material and conversations were inappropriate for children and posed a threat to their innocence. Normalising judgements, coupled with the panoptic gaze are central to the apparatus of social control which is characteristic of biopower. Jackson and Scott (2010) posit that the surveillance of children's sexual lives has 
historically been underpinned by an additional motivation to prolong childhood. Sexualisation and predator discourses offer another contemporary example of biopower. They have led to heightened surveillance of children because of their perceived vulnerability to sexual danger resulting in control since, according to Foucault (1977), control is internalised and exercised through universal surveillance rather than force.

A conspicuous absence in the fathers' discussions and in the literature relates to the child's right to learn about sexuality. Power, according to Foucault (1982) is an action that requires two consenting parties and a possibility of choice. In the current discourses children are disempowered because they have no choice and the normative framework is to refuse children such information. Not only does this mean that they are rendered more vulnerable, they are also unlikely to be prepared for the onset of puberty given the earlier physical maturation of boys and girls (Goldman 2008).

It could also be argued that the fathers who participated in this study were disempowered because they were seemingly unaware of how their practices were influenced by the subtle coercions of governmentality. Warnings regarding the perils of childhood sexualisation implicitly advise that the good family will discourage sexuality-orientated discussions with their children; thus expert discourses rendered the fathers as self-policing subjects. Their lack of resistance led to the production of a 'docile body' (Foucault 1977: 136) that may be subjected, used, transformed and improved. With the exception of Neil, the fathers chose to align their practices with 'expert' recommendations. Rather than challenging the centrality of expertise and, indeed, the legitimacy of such experts, they endorsed disciplinary technologies. As seen in this study, such technologies employ powerful discourses that shape regimes of truth and incorporate 'normalising judgement(s)' (Foucault 1977: 177) which qualify or disqualify individuals as 'fit and proper members of the social order' (Danaher et al. 2000: 61). Individual behaviour is, therefore, constrained through 'a set of standards and values associated with normality which are set into play by a network of ostensibly beneficent ... forms of knowledge' (McNay 1994: 94). Thus, the childhood sexualisation discourse reinforces the notion that childhood sexuality is an expert realm in which only experts can legitimately advise on how the subject should be tackled.

\section{Limitations}

The interpretations presented in this study were those of the research team and they were, inevitably, shaped by the researchers' values and choice of theoretical lens; subjectivity is, therefore, an inevitable feature of this study. In addition, the role of language can be problematic in IPA studies in that language can construct rather than describe reality, and there is, therefore, a risk that the interview transcripts in this study told more about the way in which the fathers talked about their experiences than the experience itself. As Willig (2001) points out, individuals may struggle to use language in a way that accurately conveys the subtleties and nuances of their experience and, as with all studies of this nature, there is a risk that the fathers' dialogues reflected what they perceived to be the 'right' thing to say rather than their authentic accounts. The small sample size and homogenous nature of the sample that is required of IPA studies are further limitations to the generalisations that can be drawn from this study. This study provides an insight into a population that is not representative of all fathers since the sample was exclusively white, mature, educated, professional, heterosexual and the fathers lived with their children and the mothers of their children full-time. It, therefore, does not provide an insight in to the perceptions and practices of groups such as young fathers, fathers of different cultures, fathers who are socio-economically disadvantaged and 
those who do not identify themselves as heterosexual. In addition, the socio-economic status of the fathers may have given particular prominence to issues such as the 'stranger-danger' discourse which is frequently suggested to be of greatest concern to white 'middle class' parents (Pain 2006). Furthermore, due to the self-selected nature of the fathers who participated in the study, the findings and interpretations need to be placed in context since the sample may over represent fathers who are more favourable towards discussing sexuality with their children than other fathers. Further research that selects from different groups and draws comparisons across groups is, therefore, required.

\section{Conclusion}

A significant barrier to father-child sexuality communication appears to relate to the childhood innocence ideal. Notions around childhood and sexual innocence are held to be of such significance to social relations and systems of regulation that political institutions, the media, religious authorities and others use the sexualisation agenda as a quiet coercion (Foucault 1977) in order to produce and reproduce social and political norms that suppress open dialogue. Such conversations are, therefore, difficult and subjugated and normative behaviours have been established that question the need for children to learn about sexuality. Thus the panoptic gaze is broadened not only to include surveillance of our children's learning about sexuality but to extend to fathers' concerns regarding how they will be judged by others if their children 'know too much' about their bodies, relationships and reproduction (Stone 2015). As Foucault argues, the most powerful effect of the panoptic gaze is the attitude of self-policing that it engenders in its subjects; 'he becomes the principle of his own subjection' (Foucault 1977: 209). Thus biopower operates through these technologies of normalisation and the panoptic gaze, through a 'subtle, calculated technology of subjection' (Foucault 1977: 227), to produce self-regulating subjects which conform to societal norms to keep children in ignorance regarding sexuality. However, children are potentially rendered more vulnerable if they are kept in ignorance; thus normalising assumptions regarding the childhood innocence ideal need to be challenged and fathers need to be encouraged to align their practices with their perceptions that knowledge can play a protective role for children.

Address for correspondence: Clare Bennett, Institute of Health \& Society, University of Worcester, UK. E-mail: c.bennett@worc.ac.uk

\section{References}

Alanen, L. and Mayall, B. (eds.) (2001) Conceptualising Child-Adolescent Relations. London: Routledge. Ballard, S. and Gross, K. (2009) Exploring parental perspectives on parent-child sexual communication, American Journal of Sexuality Education, 4, 1, 40-57.

Beck, U. (1992) Risk Society: Towards a New Modernity. Trans. Ritter, M. London: Sage.

Best, R. (1983) We've All Got Scars: What Girls and Boys Learn in Elementary School. Bloomington: Indiana University Press.

Buckingham, D. and Bragg, S. (2004) Young People, Sex and the Media: The Facts of Life?. Basingstoke: Palgrave.

Campero, L., Walker, D., Atienzo, E.E. and Gutierrez, J.P. (2011) A quasi-experimental evaluation of parents as sexual health educators resulting in delayed sexual initiation and increased access to condoms, Journal of Adolescence, 34, 2, 215-23. 
Chenier, E. (2012) The natural order of disorder: pedophilia, stranger danger and the normalising family, Sexuality and Culture, 16, 2, 172-86.

Corsaro, W.A. (1992) Interpretive reproduction in children's peer cultures, Social Psychology Quarterly, $55,2,160-77$.

Danaher, G., Schirato, T. and Webb, J. (2000) Understanding Foucault. London: Sage.

Davies, C. and Robinson, K. (2010) Hatching babies and stork deliveries: risk and regulation in the construction of children's sexual knowledge, Contemporary Issues in Early Childhood, 11, 3, 249-62.

DiIorio, C., Pluhar, E. and Belcher, L. (2003) Parent-child communication about sexuality, Journal of HIV/AIDS Prevention and Education for Adolescents and Children, 5, 3-4, 7-32.

Dyson, S. and Smith, E. (2012) 'There are lots of different kinds of normal': families and sex education styles, approaches and concerns, Sex Education, 12, 2, 219-29.

Egan, R.D. (2013) Becoming Sexual. A Critical Appraisal of the Sexualization of Girls. Cambridge: Polity Press.

Foucault, M. (1972) The Archaeology of Knowledge. Trans. Sheridan Smith, A. M. London: Tavistock.

Foucault, M. (1977) Discipline and Punish. The Birth of the Prison. Trans. Sheridan Smith, A. M. London: Penguin.

Foucault, M. (1978) The Will to Knowledge. The History of Sexuality: 1. Trans. Hurley, R. London: Penguin.

Foucault, M. (1979) Governmentality. Ideology and Consciousness, 6, Summer, 5-21.

Foucault, M. (1982) Subject and power: Afterword. In Dreyfus, H. L. and Rabinow, P. (eds.) Michel Foucault: Beyond Structuralism and Hermeneutics. Chicago: University of Chicago Press.

Fox, N. (1993) Postmodernism, Sociology and Health. Toronto: University of Toronto Press.

Frankham, J. (2006) Sexual antimonies and parent/child sex education: learning from foreclosure, Sexualities, 9, 2, 236-54.

Geasler, M.L., Dannison, L. and Edlund, C. (1995) Sexuality education of young children: parental concerns, Family Relations, 44, 2, 184-8.

Goldman, R. and Goldman, J. (1982) Children's Sexual Thinking. A Comparative Study of Children aged 5 to 15 Years in Australia, North America, Britain and Sweden. London: Routledge and Kegan Paul.

Goldman, J.D.G. (2008) Responding to parental objections to school sexuality education: a selection of 12 objections, Sex Education, 8, 4, 415-38.

Harden, J. (1998) Sex Acts. Practices of Femininity and Masculinity. London: Sage.

Huebner, A.J. and Howell, L.W. (2003) Examining the relationship between adolescent sexual risk-taking and perceptions of monitoring, communication and parenting styles, Journal of Adolescent Health, $33,2,71-78$.

Jackson, S. and Scott, S. (2010) Theorizing Sexuality. Maidenhead: Open University Press.

Jackson, S. and Scott, S. (2015) A sociological history of researching childhood and sexuality: continuities and discontinuities. In Renold, E., Ringrose, J. and Egan, R.D. (eds.) Children, Sexuality and Sexualization. Hampshire: Palgrave Macmillan.

James, A. (1998) From the child's point of view: issues in the social construction of childhood. In Panter-Brick, C. (ed.) Biosocial Perspectives on Children. Cambridge: Cambridge University Press.

James, A. and James, A. (2004) Constructing Childhood: Theory Policy and Social Practice. Basingstoke: Palgrave Macmillan.

James, A. and Prout, A. (1997) Constructing and Reconstructing Childhood: Contemporary Issues in the Sociological Study of Children. London: Falmer Press.

Kincaid, J. (1992) Child-Loving: The Erotic Child and Victorian Culture. London: Routledge.

Lee, N. (2002) Childhood and Society: Growing Up in an Age of Uncertainty. Buckingham: Open University Press.

Lehr, S.T., DiIorio, C., Dudley, W.N. and Lipana, J.A. (2000) The relationships between parent-adolescent communication and safer sex behaviors in college students, Journal of Family Nursing, 6, 2, 18096.

Martin, K.A. and Torres, J.M. (2014) Where did I come from? US parents' and preschool children's participation in sexual socialisation, Sex Education, 14, 2, 174-90. 
McGinn, L. (2013) Innocence, knowledge and the construction of childhood. The contradictory nature of sexuality and censorship in children's contemporary lives, Sex Education, 14, 1, 110-12.

McNay, L. (1994) Foucault: A Critical Introduction. Cambridge: Polity Press.

Miller, B.C., Benson, B. and Galbraith, K.A. (2001) Family relationships and adolescent pregnancy risk: a research synthesis, Developmental Review, 21, 1, 1-38.

Nadesan, M.H. (2008) Governmentality, Biopower, and Everyday Life. London: Routledge.

Nagamatsu, M., Saito, H. and Sato, T. (2008) Factors associated with gender differences in parent-adolescent relationships that delay first intercourse in Japan, Journal of School Health, 78, 11, 601-606.

Nguyen, S.P. and Rosengren, K.S. (2004) Parental reports of children's biological knowledge and misconceptions, International Journal of Behavioral Development, 28, 5, 411-20.

Ogle, S., Glasier, A. and Riley, S.C. (2008) Communication between parents and their children about sexual health, Contraception, 77, 4, 283-88.

Pain, R. (2006) Paranoid parenting? Rematerializing risk and fear for children, Social and Cultural Geography, 7, 2, 221-43.

Pilcher, J. (2010) What not to wear? Girls, clothing and 'showing' the body, Children and Society, 24, 6, 461-70.

Rabinow, P. and Rose, N. (2006) Biopower today, BioSocieties, 1, 2, 195-217.

Renold, E. (2005) Girls, Boys and Junior Sexualities. Exploring Children's Gender and Sexual Relations in the Primary School. London: Routledge Falmer.

Renold, E. (2013) Boys and Girls Speak Out. A Qualitative Study of Children's Gender and Sexual Cultures (Age 10-12). Cardiff: Cardiff University Press.

Robinson, K.H. (2008) In the name of 'childhood innocence' A discursive exploration of the moral panic associated with childhood and sexuality, Cultural Studies Review, 14, 2, 113-29.

Robinson, K. H. (2013) Innocence, Knowledge and the Construction of Childhood. The Contradictory Nature of Sexuality and Censorship in Children's Contemporary Lives. London: Routledge.

Rysst, M. (2010) I am only 10 years old: femininities, clothing fashion codes and the intergenerational gap of interpretation of young girls' clothes, Childhood, 17, 1, 76-93.

Smith, J.A. (1996) Beyond the divide between cognition and discourse: using interpretative phenomenological analysis in health psychology, Psychology and Health, 11, 2, 261-71.

Smith, J.A. (2004) Reflecting on the development of interpretative phenomenological analysis and its contribution to qualitative research in psychology, Qualitative Research in Psychology, 1, 1, 39-54.

Smith, J. A. and Eatough, V. (2012) Interpretive Phenomenological Analysis. In Breakwell, G. M., Smith, J. A. and Wright, D. B. (eds.) Research Methods in Psychology, 4th edn. London: Sage.

Smith, J.A. and Eatough, V. (2016) Interpretative Phenomenological Analysis. In Lyons, E. and Coyle, A. (eds.) Analysing Qualitative Data in Psychology. London: Sage.

Smith, J. A., Flowers, P. and Larkin, M. (2009) Interpretative Phenomenological Analysis. Theory, Method and Research. London: Sage.

Somers, C.L. and Paulson, S.E. (2000) Students' perceptions of parent-adolescent closeness and communication about sexuality: relations with sexual knowledge, attitudes and behaviors, Journal of Adolescence, 23, 5, 629-644.

Stone, N., Ingham, R. and Gibbins, K. (2013) Where do babies come from? Barriers to early sexuality communication between parents and young children, Sex Education, 13, 2, 228-240.

Stone, N., Bengry-Howell, A., Ingham, R. and McGinn, L. (2015a) Early Sexual Socialisation and Sexuality Education: Parental Perspectives. 'How Should We Tell The Children?'. Southampton: University of Southampton.

Stone, N., Ingham, R., McGinn, L. and Bengry-Howell, A. (2015b) Talking to Young Children About Relationships, Babies and Bodies: What Parents Think. Southampton: University of Southampton.

Vygotsky, L. (1978) Mind in Society: Development of Higher Psychological Processes. Cambridge: Harvard University Press.

Walsh, A., Parker, E. and Cushing, A. (1999) 'How am I gonna answer this one?': A discourse analysis of fathers' accounts of providing sexuality education for young sons, Canadian Journal of Human Sexuality, 8, 2, 103-14. 
Widman, L., Welsh, D.P., McNulty, J.K. and Little, K.C. (2006) Sexual communication and contraceptive use in adolescent dating couples, Journal of Adolescent Health, 39, 6, 893-9.

Widman, L., Choukas-Bradley, S., Noar, S.M., Nesi, J. and Garrett, K. (2016) Parent-adolescent sexual communication and adolescent safer sex behavior: a meta-analysis, JAMA Pediatrics, 170, 1, 52-61.

Willig, C. (2001) Introducing Qualitative Research in Psychology. Buckingham: Open University Press.

Wilson, E. and Koo, H. (2010) Mothers, fathers, sons, and daughters: gender differences in factors associated with parent-child communication about sexual topics, Reproductive Health, 7, 1, 1-9.

Wilson, E. K., Dalberth, B. T. and Koo, H. P. (2010) 'We're the heroes!': Fathers' perspectives on their role in protecting their preteenage children from sexual risk, Perspectives on Sexual and Reproductive Health, 42, 2, 117-124.

Wyckoff, S. C., Miller, K. S., Forehand, R., Bau, J. J., et al. (2008) Patterns of sexuality communication between preadolescents and their mothers and fathers, Journal of Child and Family Studies, 17, 5, 649-62.

Wyness, M. (2015) Childhood. Cambridge: Polity Press. 


\section{Author Query Form}

\section{Journal: $\quad$ SHIL \\ Article: $\quad 12591$}

Dear Author,

During the copy-editing of your paper, the following queries arose. Please respond to these by marking up your proofs with the necessary changes/additions. Please write your answers on the query sheet if there is insufficient space on the page proofs. Please write clearly and follow the conventions shown on the attached corrections sheet. If returning the proof by fax do not write too close to the paper's edge. Please remember that illegible mark-ups may delay publication.

Many thanks for your assistance.

\begin{tabular}{|l|l|l|}
\hline Query reference & Query & Remarks \\
\hline 1 & $\begin{array}{l}\text { AUTHOR: Please confirm that given names } \\
\text { (red) and surnames/family names (green) have } \\
\text { been identified correctly. }\end{array}$ & $\begin{array}{l}\text { AUTHOR: *Anon 2015 - please provide details } \\
\text { and full details for the references. }\end{array}$ \\
\hline 2 & $\begin{array}{l}\text { AUTHOR: *Anon 2015 - please provide details } \\
\text { and full details for the references. }\end{array}$ & \\
\hline 3 &
\end{tabular}




\section{Please correct and return this set}

Please use the proof correction marks shown below for all alterations and corrections. If you wish to return your proof by fax you should ensure that all amendments are written clearly in dark ink and are made well within the page margins.

\begin{tabular}{|c|c|c|}
\hline Instruction to printer & Textual mark & Marginal mark \\
\hline Leave unchanged & ... under matter to remain & ( \\
\hline $\begin{array}{l}\text { Insert in text the matter } \\
\text { indicated in the margin }\end{array}$ & $h$ & $\begin{array}{l}\text { New matter followed by } \\
h \text { or } h \otimes\end{array}$ \\
\hline Delete & $\begin{array}{l}\text { I through single character, rule or underline } \\
\text { or }\end{array}$ & $\sigma$ or $\sigma / \otimes$ \\
\hline $\begin{array}{l}\text { Substitute character or } \\
\text { substitute part of one or } \\
\text { more word(s) }\end{array}$ & / through letter or & $\begin{array}{l}\text { new character / or } \\
\text { new characters / }\end{array}$ \\
\hline Change to italics & — under matter to be changed & $\leftarrow$ \\
\hline Change to capitals & $\equiv$ under matter to be changed & $\equiv$ \\
\hline Change to small capitals & $=$ under matter to be changed & $=$ \\
\hline Change to bold type & $\sim$ under matter to be changed & $\sim$ \\
\hline Change to bold italic & $\approx$ under matter to be changed & $\underline{s i n}$ \\
\hline Change to lower case & Encircle matter to be changed & $\not$ \\
\hline Change italic to upright type & (As above) & \\
\hline Change bold to non-bold type & (As above) & \\
\hline Insert 'superior' character & $\begin{array}{l}\text { I through character or } \\
K \text { where required }\end{array}$ & $\begin{array}{l}y^{\prime} \text { or } y \\
\text { under character } \\
\text { e.g. } y^{2} \text { or } y^{2}\end{array}$ \\
\hline Insert 'inferior' character & (As above) & $\begin{array}{l}\text { L } \\
\text { over character } \\
\text { e.g. } \hat{\imath}\end{array}$ \\
\hline Insert full stop & (As above) & $\odot$ \\
\hline Insert comma & (As above) & , \\
\hline Insert single quotation marks & (As above) & $\begin{array}{l}\dot{y} \text { or } \dot{X} \text { and/or } \\
\dot{y} \text { or } \dot{X}\end{array}$ \\
\hline Insert double quotation marks & (As above) & $\begin{array}{l}\ddot{y} \text { or } \ddot{y} \text { and/or } \\
\ddot{y} \text { or } \ddot{x}\end{array}$ \\
\hline Insert hyphen & (As above) & $1-1$ \\
\hline Start new paragraph & $\digamma$ & 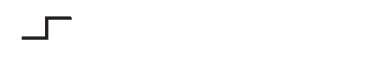 \\
\hline No new paragraph & $\infty$ & $\omega$ \\
\hline Transpose & $\sqcup$ & ᄃ \\
\hline Close up & linking $\bigcirc$ characters & \\
\hline $\begin{array}{l}\text { Insert or substitute space } \\
\text { between characters or words }\end{array}$ & $\begin{array}{l}\text { I through character or } \\
\Lambda \text { where required }\end{array}$ & \\
\hline $\begin{array}{l}\text { Reduce space between } \\
\text { characters or words }\end{array}$ & $\begin{array}{l}\text { between characters or } \\
\text { words affected }\end{array}$ & $\uparrow$ \\
\hline
\end{tabular}

